\title{
Pengaruh Jumlah Penduduk Terhadap Konsumsi Beras di Kecamatan Asparaga Kabupaten Gorontalo
}

\section{Idrus Ismail}

\author{
Kepala Desa Tiohu, Kecamatan Asparaga, Kabupaten Gorontalo
} email: idrusismail@gmail.com

\begin{abstract}
This study aims to determine the effect of Total Population on Rice Consumption in the District of Asparaga Gorontalo Regency can be fulfilled. The data used in this study Primary data obtained directly from the object of research either through interviews or from the observation (observation) in the community in District Asparaga Gorontalo and secondary data that is sourced from documents in related institutions in District Asparaga Regency Gorontalo. The method of analysis used is simple regression analysis method to see the relation of population to rice consumption with the help of SPSS Program which used in analyzing data.

The results obtained from the data that has been collected to obtain the regression equation $Y=601.439+0.997 X$ means the Number of residents in District Asparaga Gorontalo regency in every year very little effect
\end{abstract}

Keywords: Population, concumption of Rice

\section{PENDAHULUAN}

Masalah penduduk ini merupakan isu nasional yang perlu menjadi perhatian semua pihak terutama dikota-kota besar yang dapat menghambat berkembangnya negara ini kearah lebih maju, sehingganya pemerintah melakukan programnya dalam mengatasi kepadatan jumlah penduduk melalui Program Keluarga Berencana dengan 2 orang anak cukup. Hal ini perlu ditingkatkan pada setiap tahun karena semakin meningkat jumlah penduduk maka beban ratio atau beban tanggungan perkeluarga akan menjadi lebih besar dibanding dengan jumlah keluarga yang bekerja pada setiap tahunnya.

Adapun permasalahan penduduk ini menjadi pemikiran kita semua karena dikwatirkan antara jumlah penduduk dengan ketersediaan jumlah bahan makanan berupa beras akan berbanding terbalik, sebagaimana dikutip dari seorang para ahli ekonomi pada zaman klasik yakni Thomas Maltus mengatakan bahwa jumlah penduduk dihitung dengan deret hitung dan makanan dihitung dengan deret ukur, artinya setiap ketambahan 
jumlah penduduk 1 (satu) orang maka makanan harus bertambah 2(dua) $\mathrm{Kg}$ beras, setiap ketambahan jumlah penduduk 2 (dua) orang maka makanan harus bertambah 4(empat) Kg beras demikian seterusnya.

Makanya dengan konsep tersebut perlu ditinjau kembali apakah di setiap daerah tertentu menghendaki demikian, sehingga kalau bentuk pertumbuhan penduduk dan jumlah makanan sedemikian halnya maka angka devendensi antar keluarga semakin menjamin kehidupan akan kebutuhan pangan secara tersedia dan terpenuhi pada masyarakat pada umumnya akan semakin sejahtera.

Namun dengan berkembangnya jumlah penduduk setelah pemekaran dan sampai sekarang ini telah terjadi pertumbuhan ekonomi yang sangat baik sehingga dapat memberikan peluang berbagai rumah tangga untuk meningkatkan aktifitasnya sehari-hari dan dapat memicu mempercepat proses perubahan struktur ekonomi keluarga mereka yang meningkat dan diikuti pula dengan pola hidup mereka yang semakin baik.

Kecamatan Asparaga yang terletak diujung barat Kabupaten Gorontalo maka sejak terbentuk menjadi sebuah kecamatan yang definitif, maka dengan kekuatan serta kemampuan potensi yang dimiliki terus berupaya mengembangkan pengelolaan potensinya tersebut untuk menjadi faktor utama dalam meningkatkan kemampuan ekonomi masyarakat secara mandiri dan berkembang sampai keseluruh lapisan masyarakat secara umum. Adapun potensi yang utama dimiliki oleh kecamatan ini adalah pertanian, peternakan serta usaha jasa lainnya.

Untuk itu dengan potensi tersebut menjadikan masyarakat sekitarnya terus mengembangkan kinerja mereka terutama dalam peningkatan pemenuhan terhadap konsumsi pada komoditi beras sebagai makanan sehari-hari bagi keluarganya, sehingga mulai sekarang ini perlu dipikirkan terlebih dahulu adalah pentingnya perencanaan konsumsinya tersebut manakala jumlah penduduk semakin berkembang terus menerus karena perkembangan pertumbuhan ekonomi masyarakat sekarang ini akan dapat menggeser pula semakin meningkat kebutuhan akan pangan bagi keluarganya.

Dengan demikian partisipasi seluruh masyarakat bersama-sama dengan pemerintah terus berupaya semaksimal mungkin dalam menciptakan berbagai kebijakan terhadap pola hidup yang baik dan benar serta kebijakan peningkatan pemberdayaan kegiatan bidang pertanian terutama pada upaya penyediaan komoditi beras dalam menghadapi kendisi apabila jumlah penduduk semakin meningkat ditahun akan datang, sehingga kekhawatiran terhadap defisitnya persediaan beras walaupun jumlah penduduk semakin meningkat tidak akan dialami oleh seluruh lapisan masyarakat pada umumnya.

Kemudian dengan berkembangnya jumlah penduduk di Kecamatan Asparaga tentunya akan membutuhkan pasokan beras sebagai konsumsi mereka sehingga hal ini akan memberikan peluang bagi para pedagang dan para petani untuk berusaha memberikan kemampuan menyediakan sejumlah pasokan tersebut sesuai dengan perkembangan jumlah penduduk setiap tahunnya, mengingat komodoti ini merupakan kebutuhan pokok bagi seluruh masyarakat.

Berdasarkan pada uraian latar belakang diatas, yang menjadi pokok masalah dalam penelitian ini adalah "Pengaruh Jumlah Penduduk Terhadap Konsumsi Beras di Kecamatan Asparaga Kabupaten Gorontalo". 


\subsection{Pengertian Perencanaan Pembangunan}

\subsubsection{Pengertian Ekonomi Perencanaan}

Menurut Kuncoro (2012 : 53), berdasarkan undang-undang no.25/2005 tentang Sistim Perencanaan Pembangnan Nasional, dikenal empat pendekatan dalam proses perencanaan yaitu proses politik, teknokratik, partisipatif, serta bottom up dan top down. Keempat proses perencanaan tersebut memiliki pendekatan dan ciri tersendiri adalah :

1. Proses Politik. Pemilihan Presiden atau Kepala Daerah dipandang sebagai proses penyusunan rencana karena rakyat pemilih menentukan pilihanya. Berdasarkan program-program pembangunan yang ditawarkan oleh setiap calon Presiden atau Kepala Daerah.

2. Proses Teknokratif. Perencanaan yang dilakukan oleh perencana professional atau lembaga/unit organisasi yang secara funsional melakukan perencanaan dilaksanakan dengan menggunakan metode dan kerangka berfikir ilmiah.

3. Proses Partisipatif. Perencanaan yang melibatkan pihak yang berkepentingan terhadap pembangunan (Stakeholder) yang antara lain melalui pelaksanaan Musrenbang.

4. Proses Bottom Up dan Top Down. Perencanaan yang aliran prosesnya dari atas kebawah atau dari bawah keatas dalam hirarki Pemerintahan (menurut jenjang pemerintahan).

\subsubsection{Pengertian Ekonomi Pembangunan}

Menurut Irawan dan Suparmako (2011 : 5) pembangunan ekonomi adalah usaha-usaha untuk meningkatkan taraf hidup suatu bangsa yang sering kali diukur dengan tinggi rendahnya pendapatan riil per-kapita. Jadi tujuan pembangunan ekonomi disamping untuk menaikan pendapatan nasional riil juga untuk meningkatkan produktifitas. Pada umumnya dapat dikatakan bahwa tingkat out put pada suatu saat tertentu ditentukan oleh tersedianya atau digunakan baik sumber daya alam maupun sumber daya manusia, tingkat teknologi, keadaan pasar dan kerangka kehidupan ekonomi (system perekonomian) serta sikap dari output itu sendiri.

\subsection{Pengertian Permintaan}

Menurut Mupangga (2011:22) mendefinisikan permintaan adalah berbagai jumlah barang dan jasa yang diminta oleh pembeli pada berbagai kemungkinan pada tingkat harga dalam kurun waktu tertentu dalam suatu pasar tertentu.

\subsection{Pengertian Penduduk}

Menurut Elvira, yang dikutif pada artikel mengatakan Penduduk ialah orang atau individu yang tinggal atau menetap pada suatu daerah tertentu dalam jangka waktu yang lama. Ada beberapa pengertian yang secara singkat perlu diketahui untuk mendukung tulisan ini dan merupakan bahan acuan dalam mengembangkan aplikasi yang ada. Pengertian tersebut adalah:

\subsubsection{Fertilitas}

Fertilitas atau kelahiran merupakan salah satu faktor penambah jumlah penduduk disamping migrasi masuk. Istilah fertilitas juga dapat diartikan sebagai kemampuan seorang wanita untuk menghasilkan kelahiran hidup. Kelahiran bayi membawa konsekuensi pemenuhan kebutuhan tumbuh kembang bayi tersebut, termasuk pemenuhan gizi, kecukupan kalori dan perawatan kesehatan. Pada gilirannya, bayi ini akan 
tumbuh menjadi anak usia sekolah yang menuntut pendidikan, lalu masuk angkatan kerja dan menuntut pekerjaan. Bayi perempuan akan tumbuh menjadi remaja perempuan dan perempuan usia subur yang akan menikah dan melahirkan bayi.

\subsubsection{Mortalitas}

Mortalitas atau kematian merupakan salah satu faktor yang dapat mempengaruhi perubahan penduduk. Komponen ini bukan saja berpengaruh bagi pemerintah secara keseluruhan melainkan perlu juga bagi pihak swasta, terutama yang berkecimpung dalam bidang ekonomi dan kesehatan. Perlunya data ini dapat menunjang proyeksi penduduk guna perencanaan pembangunan.

\subsection{Pengertian Konsumsi}

Konsumsi merupakan sebuah kata yang berasal dari Bahasa Inggris yaitu "Consumption". Konsumsi artinya pemenuhan akan makanan dan minuman. Konsumsi mempunyai pengertian yang lebih luas yaitu seluruh pembelian barang dan jasa akhir yang sudah siap dikonsumsi oleh rumah tangga untuk memenuhi kebutuhan (Eachern, 2001:490). Menurut T Gilarso (2003:89), konsumsi merupakan titik pangkal dan tujuan akhir seluruh kegiatan ekonomi masyarakat.

\subsection{Daerah dan Waktu Penelitian}

\section{METODE PENELITIAN}

3.1.1. Daerah Penelitian. Adapun yang menjadi obyek penelitian dalam penulisan ini adalah Kecamatan Asparaga Kabupaten Gorontalo dan lokasi penelitian ini dipilih karena pertimbangan penghematan biaya serta kesesuain sumber data terhadap penelitian.

3.1.2. Waktu Penelitian. Adapun waktu penelitian yang digunakan sangat disesuaikan dengan kalender akademik tentang penyusunan skripsi, yakni selama 3 bulan.

\subsection{Definisi Operasional variabel}

Untuk menghindari kesalahpahaman dalam penafsiran terhadap beberapa variable yang digunakan dalam penelitian ini, maka peneliti memberikan definisi operasional variabel yang menjadi batasan sebagai berikut

3.2.1. Konsumsi adalah pemenuhan akan makanan dan minuman. Konsumsi mempunyai pengertian yang lebih luas yaitu seluruh pembelian barang dan jasa akhir yang sudah siap dikonsumsi oleh rumah tangga untuk memenuhi kebutuhan

3.2.2. Penduduk adalah orang atau individu yang tinggal atau menetap pada suatu daerah tertentu dalam jangka waktu yang lama.

\subsection{Metode Pengumpulan Data}

Metode yang digunakan oleh penulis dalam pengumpulan data adalah sebagai berikut :

a. Penelitian Kepustakaan (Library research) yaitu mengadakan pengkajian terhadap literatur-literatur yang relevan dengan masalah yang dibahas. Hal ini dimaksudkan untuk menunjang dalam proses penganalisaan dalam keperluan konsep-konsep operasionalisasi varabel-variabel analisis.

b. Penelitian lapangan (Field research) yang merupakan penelitian langsung ke obyek penelitian melalui teknik pengumpulan data sebagai berikut : 
1. Observasi yaitu dengan mengamati dan meneliti segala sesuatu yang ada hubungannya dengan penelitian.

2. Wawancara yaitu mengadakan wawancara langsung kepada pihak kantor Dinas terkait yang berhubungan dengan obyek penelitian.

3. Dokumentasi yaitu mengadakan pencatatan dokumen dan informasi yang berkaitan dengan obyek penelitian tersebut.

\subsection{Jenis dan Sumber Data}

3.4.1. Jenis Data

1. Data Kuantitatif yaitu merupakan data (dinyatakan dalam angka-angka) yang diperoleh dari hasil olahan data primer dan data sekunder

2. Data Kualitatif yaitu data yang tidak dihitung atau bukan berupa angkaangka tetapi berupa kalimat-kalimat yang diperoleh dari hasil wawancara melalui kuisioner dengan berbagai pihak.

3.4.2. Sumber data

1. Data Primer, merupakan data yang diperoleh langsung dari obyek penelitian baik melalui wawancara maupun dari hasil pengamatan (observasi) pada masyarakat di kecamatan Asparaga Kabupaten Gorontalo.

2. Data sekunder yaitu data yang bersumber dari dokumen-dokumen pada instansi terkait yang ada di Kecamatan Asparaga Kabupaten Gorontalo.

\subsection{Metode Analisis}

3.5.1 Metode analisis Kualitatif. Dalam hal ini akan dipaparkan berdasarkan analisis kondisi objektif dan temuan-temuan yang dihubungkan dengan teori-teori ilmiah, sehingga diperoleh gambaran secara sistimatis, faktual dan aktual serta solusi-solusi terhadap pemecahannya.

3.5.2Metode analisis Kuantitatif. Metode ini digunakan dengan cara menggambarkan jumlah permintaan konsumsi akan beras dihubungkan dengan jumlah penduduk di Kecamatan Asparaga pada setiap tahun.

Selanjutnya, Metode analisis yang digunakan yaitu metode analisa regresi sederhana untuk melihat hubungan jumlah penduduk terhadap konsumsi beras, sebagaimana dikutip Supranto (2001:57) adalah sebagai berikut:

$\mathrm{Y}=\mathrm{a}+\mathrm{bX}$ Artinya adalah :

$\mathrm{Y}=$ Jumlah Konsumsi $(\mathrm{Kg})$

$\mathrm{X}=$ Jumlah Penduduk (Jiwa)

a $=$ Konstanta dalam Persamaan Trend

$\mathrm{b} \quad=$ Tingkat Kecendrungan

Untuk pengolahan data analisis akan dilakukan dengan program SPSS

\section{HASIL PENELITIAN DAN PEMBAHASAN}

4.1 Deskripsi Variabel-Variabel Penelitian

a. Identifikasi Jumlah penduduk pertahun

Penduduk merupakan salah komponen dalam penentuan kebijakan dalam berbagai kegiatan ekonomi baik bagi pemerintah maupun sebagian kelompok masyarakat tertentu yang banyak bergerak pada berbagai kegiatan ekonomi lainnya seperti pedagang, pengusaha dan lain sebagainya. Disamping itu pula penduduk merupakan persyaratan yang mutlak terbentuknya suatu Negara, daerah provinsi, kabupaten dan bahkan sampai wilayah terkecilpun manakala mengalami bentuk wilayah pemekaran sekarang ini.

Adapun perkembangan penduduk dapat terjadi secara cepat tergantung pada peningkatan pendapatan keluarga mereka dimana bertambahnya 
penduduk diakibatkan oleh kemampuan masyarakat melalukan aktifitas status keluarganya misalnya melakukan pernikahan bagi keluarganya sehingga dengan demikian akan bisa terjadi upaya kelahiran keluarga tersebut, perpindahan penduduk dari daerah padat penduduk kedaerah yang kurang penduduk melalui transmigrasi dan sebaliknya melalui proses urbanisasi antara daerah tertentu.

Dalam kajian ini penduduk dijadikan sebagai bahan pembanding pada kondisi perkembangan jumlah konsumsi dengan diperhadapkan pada salah satu komoditi yakni beras sebagaimana menjadi kebutuhan pokok bagi masyarakat secara umum. Dengan perkembangan jumlah penduduk pada setiap tahun apakah standarisasi komsumsi beras pada setiap tahun dapat terpenuhi atau belum tanpa melihat jumlah persediaan beras dipasar.

Berikut ini akan diuraikan perkembangan penduduk di Kecamatan Asparaga Kabupaten Gorontalo pada setiap tahunnya sehingga dapat diketahui hubungan yang menggambarkan pencapaian kebutuhan maksimal dapat tercapai atau tidak adalah sebagai berikut :

Tabel 5. Jumlah Penduduk Pertahun di Kecamatan Asparaga tahun 2011-2015

\begin{tabular}{|c|l|c|c|c|c|c|}
\hline \multirow{2}{*}{ No } & \multirow{2}{*}{ Nama Desa } & \multicolumn{5}{|c|}{ Jumlah Penduduk (jiwa/tahun) } \\
\cline { 3 - 7 } & & 2011 & 2012 & 2013 & 2014 & 2015 \\
\hline 1 & Bululi & 1547 & 1557 & 1581 & 1587 & 1058 \\
2 & Mohiyolo & 1893 & 1918 & 2130 & 2135 & 2160 \\
3 & Karya Indah & 1365 & 1374 & 1365 & 1290 & 1279 \\
4 & Pangahu & 1383 & 1396 & 1366 & 1365 & 1325 \\
5 & Tiohu & 1052 & 1058 & 1160 & 1223 & 1146 \\
6 & Prima & 1050 & 1066 & 1107 & 1127 & 1132 \\
7 & Karya Baru & 1274 & 1277 & 1282 & 1301 & 1290 \\
8 & Bontula & 1947 & 1953 & 1957 & 1992 & 1972 \\
9 & Bihe & 966 & 967 & 1152 & 850 & 844 \\
10 & Olimohulo & 816 & 842 & 863 & 892 & 936 \\
\hline & Jumlah & 13266 & 13428 & 13963 & 13761 & 13142 \\
\hline
\end{tabular}

Sumber Data, Kec. Asparaga dalam Angka

Berdasarkan pada tabel tersebut diatas bahwa antara jumlah penduduk dari tahun 2011-2015 pada setiap desa di Kecamatan Asparaga Kabuapaten Gorontalo selalu mengalami peningkatan yakni dari tahun 2011-2013 tetapi mengalami penurunan jumlah penduduk pada tahun 2014-2015. Hal ini diakibatkan karena bayak jumlah penduduk yang meninggal dan pindah kedaerah lainnya dan penyebab lainnya berhasilnya pemerintah menjalankan program Keluarga Berencana sehingga tingkat kelahiran sangat rendah dibanding tahun sebelumnya.

Untuk itu gambaran jumlah penduduk tersebut sangat menentukan berkembangnya pertumbuhan ekonomi masyarakat sekitarnya karena bisa saja semakin menurun jumlah penduduk tetapi jumlah penduduk tersebut sangat produktif mendapatkan pendapatan yang maksimal maka akan memberikan gambaran tingkat depedensi rasio atau beban tanggungan setiap keluarga mereka semakin kecil yang pada akhirnya kesejahtraan mereka semakin meningkat serta kemampuan mereka menciptakan sesuatu kegiatan ekonomi produktif akan terdorong bagi keluarganya pula. 


\section{b. Identifikasi Konsumsi Beras}

Konsumsi merupakan salah satu bagian dari kebutuhan pokok manusia yang dapat diperoleh dengan mengalokasikan seluruh pendapatannya untuk dimanfaatkan dalam membeli seluruh kebutuhannya, sehingga setiap manusia selalu berusaha mengoptimalkan alat-alat pemuas kebutuhan dengan pengorbanan sekecil-kecilnya mengharapkan hasil yang semaksimal mungkin.

Untuk menyikapi hal tersebut maka konsumsi yang dimaksud adalah terkait dengan konsumsi beras sebagai kebutuhan pokok oleh setiap penduduk sehingga dapat menjamin seseorang dapat menciptakan manfaat lebih lanjut dalam perolehan tingkat pendapatan yang cukup memadai bagi keluarganya nanti setelah mengkonsumsi beras tersebut.

Sebagaimana diketahui bahwa mengkonsumsi beras dapat mempertinggi kemampuan seseorang dalam menciptakan berbagai akses apapun karena beras dapat menghasilkan kalori yang dapat memberikan semangat hidup sehingga dapat mampu bekerja dengan sekuat tenaganya dalam menggapai usaha peningkatan pendapatan bagi keluarganya melalui kegiatan ekonomi yang dijalankan setiap hari oleh setiap rumah tangga.

Untuk itu melalui kajian ini sangat diperlukan berapa banyak yang harus dibutuhkan oleh setiap penduduk pada setiap hari, atau setiap minggu sehingga mendapatkan gambaran besaran kebutuhan reel yang harus disediakan oleh pasar pada setiap waktu tertentu secara normal. Dalam arti bahwa minimal pasar berusaha menyediakan kebutuhan penduduk akan beras tersebut sesuai dengan peruntukan bagi mereka berdasarkan kemampuan ekonomi masyarakat secara keseluruhan.

Untuk itu kebutuhan akan beras bagi setiap rumah tangga memang sangat signifikan dengan kebutuhan sandang dan papan yang tetap disediakan pada setiap rumah tangga, kalau tidak demikian maka rumah tangga tersebut kurang merasakan kenikmatan kebahagiaan tersendiri dalam keluarganya sehingga bisa saja dapat merasakan kekurangan gizi, atau kesehatan lainnya yang sering menimbulkan kematian sebagaimana dialami oleh sebagian besar negara-negara miskin didunia.

Berdasarkan pada Modul hasil Survey Nasional tahun 1998 yang digunakan oleh Badan Pusat Statistik bahwa telah diambil penetapan baku bahwa setiap perkapita penduduk wajib dapat mengkonsumsi beras sebanyak $7 \mathrm{Kg}$ perminggu atau sekitar $365 \mathrm{~kg}$ dalam setahun yang dikonsumsi oleh setiap penduduk. Walaupun berdasarkan kebiasaan setiap daerah memiliki kesamaan dan perbedaan pada pola makan sehari-hari dan jenis makanan yang dikonsumsi setiap harinya tetapi kebutuhan akan beras ini merupakan kebutuhan pokok secara nasional dinegara kita.

Dengan demikian kalau patokan perhitungan tersebut berlaku secara umum bagi setiap masyarakat maka kalau persediaan beras sangat cukup dipasar kemungkinan besar akan terpenuhi, sehingga lebih jauh harus dianalisis lagi keterkaitan dengan perkembangan penduduk pada setiap tahunnya untuk mendapatkan konsumsi reel yang sebenarnya sehingga dapat diketahui apakah kebutuhan tersebut terpenuhi atau tidak.

Berikut ini akan digambarkan jumlah konsumsi beras pada setiap tahunnya berdasarkan jumlah penduduk yang didasarkan pada tabel 5 sebelumnya dikalikan dengan $365 \mathrm{~kg}$ beras pertahun perpenduduk sehingga dapat dilihat pada tabel 6 sebagai berikut : 
Tabel 6. Jumlah Konsumsi Beras di Kecamatan Asparaga tahun 2011-2015

\begin{tabular}{|c|l|c|c|c|c|c|}
\hline \multirow{2}{*}{ No } & \multirow{2}{*}{ Nama Desa } & \multicolumn{5}{|c|}{ Jumlah Konsumsi (kg/tahun) } \\
\cline { 3 - 7 } & & 2011 & 2012 & 2013 & 2014 & 2015 \\
\hline 1 & Bululi & 564.655 & 568.305 & 577.065 & 579.255 & 386.170 \\
2 & Mohiyolo & 676.345 & 700.070 & 777.450 & 779.275 & 788.400 \\
3 & Karya Indah & 478.225 & 501.510 & 498.225 & 470.850 & 466.835 \\
4 & Pangahu & 504.795 & 509.540 & 498.590 & 498.225 & 483.625 \\
5 & Tiohu & 383.980 & 386.170 & 423.400 & 446.395 & 418.290 \\
6 & Prima & 383.250 & 389.090 & 404.055 & 411.355 & 413.180 \\
7 & Karya Baru & 465.010 & 466.105 & 467.930 & 474.868 & 470.850 \\
8 & Bontula & 710.655 & 712.845 & 714.305 & 727.080 & 719.780 \\
9 & Bihe & 352.590 & 352.955 & 420.480 & 310.250 & 308.060 \\
10 & Olimohulo & 297.840 & 307.330 & 314.995 & 325.580 & 341.640 \\
\hline & Jumlah & 4.817 .345 & 4.893 .920 & 5.096 .495 & 5.023 .133 & 4.796 .830 \\
\hline
\end{tabular}

Sumber data, Hasil Olahan, 2017

Dengan memperhatikan data pada tabel diatas maka sangat nampak secara deskriptif tentang keadaan jumlah konsumsi beras yang dihitung berdasarkan jumlah penduduk semakin meningkat pada setiap tahunnya pada masing-masing desa di Kecamatan Asparaga. Dengan demikian jumlah konsumsi beras rata-rata pertahun selang dalam kurun waktu 5 tahun (2011-2015) adalah :

$$
\text { Jumlah rata-rata konsumsi pertahun }=\frac{24.627 .723}{5}=4.925 .545 \mathrm{~kg}
$$

Berikut akan digambarkan dalam tabel berikut tentang jumlah penduduk dan jumlah konsumsi disetiap Desa di Kecamatan Asaparaga sebagai berikut :

Tabel 7. Keadaan Jumlah Penduduk dan Jumlah Konsumsi beras di Kecamatan Asparaga tahun 2011-2015

\begin{tabular}{|c|c|c|c|}
\hline No & Tahun & $\begin{array}{c}\text { Jumlah Penduduk } \\
\text { (Jiwa) }\end{array}$ & $\begin{array}{c}\text { Jumlah Konsumsi Beras } \\
(\mathrm{kg})\end{array}$ \\
\hline 1 & 2011 & 13.266 & 4.817 .345 \\
2 & 2012 & 13.428 & 4.893 .920 \\
3 & 2013 & 13.963 & 5.096 .495 \\
4 & 2014 & 13.761 & 5.023 .133 \\
5 & 2015 & 13.142 & 4.796 .830 \\
\hline
\end{tabular}

Sumber data, Hasil Olahan Penelitian, 2017

Memperhatikan tabel diatas dapat diuraikan bahwa penduduk dan jumlah konsumsi beras telah dihitung berdasarkan perkembangan jumlah penduduk setiap tahunnya sehingga mendapatkan nilai jumlah konsimsi beras pertahun telah dihitung berdasarkan acuan modul yang telah digunakan oleh BPPS pusat bahwa setiap jiwa mengkonsumsi $7 \mathrm{Kg}$ perminggu atau sekitar $365 \mathrm{~kg}$ dalam setahun yang dikonsumsi oleh setiap penduduk (365 Kg dikalikan dengan jumlah penduduk).

Dalam analisis ini akan dijelaskan keterpengaruhan antara variabel bebas yakni Jumlah Konsumsi Beras dengan variabel terikat yakni Jumlah penduduk dengan menggunakan metode analisis regresi linear sederhana.

Dengan berdasarkan pada lampiran 1 print output SPSS dapat diperoleh analisis sbb: 
1. Desriptive Statistic dan Correlations

- Rata-rata indikator Jumlah penduduk adalah 13512,00 dengan standar deviasi 342,737

- Rata-rata indikator jumlah konsumsi beras adalah 4925544.60 dengan standar deviasi 130405.380

2. Variable Entered dan model Summary

- Standard error estimate untuk jumlah penduduk adalah 29.064 lebih besar dari standard deviation pada jumlah konsumsi beras adalah 130405.380 artinya regresi sangat tidak baik dijadikan sebagai prediktor untuk keseluruhan jumlah penduduk dibanding menggunakan mean atau rata-rata.

3. Anova dan Coefisients

- Dari uji Anova diperoleh F hitung 553.233 dengan tingkat signifikan 0,00 Karena probabilitasnya lebih kecil dari $553.233(0,000>0,05)$, maka model regresi signifikan untuk memprediksi jumlah penduduk di Kecamatan Asparaga karena variabel bebas signifikan mempengaruhi variabel tak bebas.

- Persamaan Regresi berganda yang diperoleh adalah : $\mathrm{Y}=601.439+$ $0, .997 \mathrm{X}$

- Keefisien a $=601.439$; artinya bahwa dalam keadaan konstan atau tidak jumlah penduduk bertambah sebesar 601.439 jiwa pada setiap tahunnya

- Koefisien $\mathrm{b}=0, .997$; artinya setiap adanya peningkatan jumlah penduduk maka Jumlah konsumsi beras di Kecamatan Asparaga akan dapat berkurang sebesar 9,97 kg per jiwa dari semula dengan asumsi faktor lain konstan.

- Nilai t hitung untuk keefisien regresi yang diperoleh adalah 23.521 dengan tingkat signifikan $23.521<0,000<0,05)$ menunjukkan bahwa koefisien regresi signifikan terhadap ketambahan jumlah penduduk pada setiap tahunnya sehingga dapat memberikan jumlah konsumsi beras akan meningkat di Kecamatan Asparaga.

- Nilai R = 0, 995 artinya memiliki hubungan korelasi antara jumlah penduduk terhadap meningkatnya jumlah konsumsi beras di Kecamatan Asparaga.

- Nilai $R^{2}=0,997$ berarti kontribusi pada perkembangan jumlah Konsumsi beras sebesar 99,7\% disebabkan oleh naik dan turunnya jumlah penduduk di Kecamatan Asaparaga dan sisanya sebesar 0,3\% dipengaruhi faktor lainnya.

Berdasarkan pada hasil analisis diatas, maka hipotesis yang diajukan bahwa jumlah penduduk berpengaruh positif dan signifikan terhadap jumlah konsumsi beras di Kecamatan Asaparaga Kabupaten Gorontalo dapat diterima.

\subsection{Pembahasan Hasil Penelitian}

Memperhatikan tabel sebelumnya maka dapat dijelaskan bahwa jumlah penduduk berpengaruh terhadap konsumsi di Kecamatan Asparaga Kabupaten Gorontalo semakin meningkat karena tergantung dari perkembangan jumlah penduduk pada masing-masing Desa setiap tahunnya (sebagaimana digambarkan pada tabel 7).

Kemudian dalam mengetahui sejauh mana hubungan antara jumlah penduduk berpengaruh terhadap konsumsi beras di Kecamatan Asparaga 
pada setiap tahunnya maka akan digunakan ukuran analisis sehingga dapat diketahui hubungan yang signifikan dari keduanya tersebut serta dapat mendeteksi jangan sampai bertentangan dengan teori klasik yakni teori Thomas R. Maltus yang mengatakan bahwa jumlah konsumsi harus relavan dengan perkembangan jumlah penduduk sehingga yang sulit adalah upaya persediaan beras bagi penduduk tersebut setiap tahunnya.

Dengan berdasarkan pada hasil penelitian dan hipotesis penelitian yang diajukan maka dapat dijelaskan variabel yang saling berhubungan dengan variabel $\mathrm{X}$, yakni jumlah penduduk yang akan mempengaruhi terhadap variabel Y yakni jumlah konsumsi beras adalah sebagai berikut :

1. Dengan berdasarkan pada formulasi dari analisa regresi sederhana yang disyaratkan pada penelitian sehingga dapat diperoleh persamaannya yaitu $\mathrm{Y}=601.439+0, .997 \mathrm{X}$ dapat dijelaskan bahwa variabel $\mathrm{X}$ memberikan keterpengaruhannya dimana semakin meningkat jumlah penduduk maka jumlah konsumsi beras di Kecamatan Asparaga pula semakin meningkat.

2. Kemudian semua variabel dependen dan variabel independen memiliki hubungan yang kuat yang dinyatakan oleh nilai $\mathrm{R}=0,995$ berarti memiliki hubungan yang kuat terhadap jumlah konsumsi beras di Kecamatan Asparaga. Dan memiliki determinasi yang saling berpengaruh yang ditujukkan oleh nilai $\mathrm{R}^{2}=0,997$ yang berarti nilai kontribusinya semakin kuat dan sisanya $0,3 \%$ dipengaruhi oleh faktor lainnya yang tidal dimasukkan dalam penelitian ini.

Demikian pula tentang konsumsi beras bagi setiap rumah tangga harus memenuhi standarisasi produksi beras terhadap penduduk mengingat beras merupakan salah satu bagian makanan yang tetap memiliki kadar vitamin dan protein nabati yang wajib dikonsumsi setiap rumah tangga. Makanya standarisasi ini merupakan alat ukur dalam menentukan total konsumsi bagi masyarakat di kecamatan Asparaga Kabupaten Gorontalo.

Disamping itu sangat jelas juga (tabel 7) bahwa jumlah konsumsi dan jumlah penduduk secara normal terjadi masih mempengaruhi karena mengingat pada masyarakat masih banyak berkembang karakter masyarakat atau kebiasaan untuk mengkonsumsi berbagai jenis makanan seperti umbi-umbian dan lainnya sebagainya sehingga jumlah penduduk kadang kala kurang mempengaruhi persediaan akan ketersediaan konsumsi beras pada setiap tahunnya.

Kalau dihubungankan dengan penelitian terdahulu menurut penelitian oleh Lamatenggo, 2015 dengan judul "Pengaruh Program Pemberdayaan Kelembagaan Kesejahteraan Sosial terhadap Jumlah Penduduk Miskin di Kecamatan Limboto Kabupaten Gorontalo" yang dengan hasil penelitiannya menunjukkan bahwa antara Variabel $\mathrm{X}$ tentang Jumlah alokasi dana bantuan program Pemberdayaan Kesejahteraan Keluarga Sosial sangat memiliki keterpengaruhan terhadap variabel $\mathrm{Y}$ yakni jumlah penduduk miskin di Kecamatan Limboto semakin menurun sehingga hal ini perlu ditingkatkan pada setiap tahun pada anggaran berikutnya. Maka berdasarkan penelitian hanya membahas tentang jumlah penduduk berpengaruh terhadap konsumsi beras di Kecamatan Asparaga Kabupaten Gorontalo.

Dengan demikian perbedaannya adalah pada masing-masing variable $\mathrm{X}$ yang berbeda dimana penelitian terdahulu hanya melihat Dana program pemberdayaan kelembagaan Kesejahtraan sosial dan variabel Y melihat 
jumlah penduduk miskin sedangkan penelitian ini melihat jumlah penduduk dan Variabel Y melihat jumlah konsumsi beras saja.

\section{SIMPULAN DAN SARAN}

\subsection{Simpulan}

1. Berdasarkan analisa dan uraian dalam bab-bab sebelumnya maka penulis dapat menarik kesimpulan sebagai berikut :

2. Dengan berdasarkan pada hasil penelitian yang dilakukan dari data yang telah terkumpul dan analisa lebih lanjut diperoleh persamaan regresinya $\mathrm{Y}=601.439+0,997 \mathrm{X}$ adalah berarti Jumlah penduduk di Kecamatan Asparaga Kabupaten Gorontalo pada setiap tahunnya sangat berpengaruh positif terhadap jumlah kensumsi beras sehingga hal ini dapat memberikan kemungkinan apabila jumlah penduduk bertambah maka teori Maltus menjadi acuan yang harus dikembangkan di masyarakat pada setiap tahunnya.

3. Dengan terbukti bahwa jumlah penduduk pada setiap tahunnya yang dibuktikan dengan nilai $\mathrm{R}=0,997$ berarti keterpengaruhannya hanya sebesar 99,7 dan sebesar 0,995\% dipengaruhi oleh faktor lainnya yang tidak dimasukkan dalam variabel penelitian ini seperti kebiasaan pola makan dari hasil pertaniannya sendiri, masih banyak masyarakat miskin yang tidak mampu mengkonsumsi beras sehari-hari dan lainnya.

\subsection{Saran}

1. Dengan dibuktikannya hasil penelitian ini dimana dapat terjadi jumlah penduduk akan berpengaruh terhadap konsumsi beras maka pemerintah harus menciptakan program Swasembada beras pada setiap tahunnya karena hal ini untuk mengantisipasi apabila terjadi peningkatan jumlah penduduk yang meningkat maka solusinya sudah dapat terantisipasinya dengan persediaan beras tersebut.

2. Dalam memotivasi pentingnya mengkonsumsi beras bagi kekuatan tubuh para penduduk mengingat makanan berupa beras ini sangat memiliki kandungan gizi yang tinggi untuk membangun tubuh yang sehat dibanding dengan jenis makanan lainnya maka pemerintah perlu melakukan kampanye secara besar-besaran melalui program hidup sehat dengan tema "Tingkatkan makan- makanan bergizi dan berkalori tinggi seperti Beras" tanpa harus mengabaikan program pemerintah tingkatkan makanan yang sifatnya non beras alias paket hemat pada masyarakat.

\section{REFERENSI}

Adiningsih, Sri, 2001, Statistik edisi ke tiga, Penerbit BPFE, Yokyakarta Duhengo, Husain, 2016, Kecamatan Asparaga Dalam Angka, Penerbit Kantor Badan Pusat Statistik Kabupaten Gorontalo

Elvira, DF, 2016, Suatu Artikel pada PDF, yang dikutif dan diakses pada tanggal 29 November 2016

Jhingan, ML, 2004, Ekonomi Pembangunan dan Perencanaan, Penerbit PT Rajagrafindo, Jakarta

Kaharu, Usman, 2004, Ekonomi Pembangunan, Penerbit Nurul Jannah, Gorontalo 
Lamatenggo, Yuyun, 2015, Pengaruh Program Pemberdayaan Kelembagaan Kesejahteraan Sosial terhadap Jumlah Penduduk Miskin di Kecamatan Limboto, Skripsi Mahasiswa, Penerbit Fakultas Ekonomi Universitas Gorontalo

Mupangga, Herwin, 2011, Pengantar Ilmu Ekonomi Teori dan Aplikasi, Penerbit MQS Publishing, Bandung

Rahardja, Pratama dan Manurung Mandala, 2010, Teori Ekonomi Mikro suatu pengantar, Edisi ke Empat, Penerbit Fakultas Ekonomi Universitas Indonesia. Jakarta

Rahardja, Pratama dan Manurung Mandala, 2005, Teori Ekonomi Makro suatu pengantar, Edisi ke Tiga, Penerbit Fakultas Ekonomi Universitas Indonesia. Jakarta

Subagiyo, Ahmad, 2016, Konsumsi, Tabungan dan Investasi, diakses tanggal 29 November 2016

Suparmoko, M dkk, 2000, Pokok - Pokok Ekonomika, Penerbit BPFE, Yokyakarta

Sukirno, Sadono, 2005, Mikro Ekonomi Teori Pengantar, Penerbit Raja Grafido Persada, Jakarta

Susenas, Juli 2008, Pedoman Modul Survey Sosial Ekonomi Nasional, Buku V, Penerbit Badan Pusat Statistik, Jakarta

Taufik, B, 2002, Mikro Ekonomi untuk Kebijakan Publik:Buku Pintar Ekonomi, Penerbit Pustaka Petronomika, Jakarta

Wardayadi, 2016, Konsumsi, tabungan dan Investasi, Materi ajar, Wordpress.com, yang diakses 29 November 2016 